\title{
PTPRT wt Allele
}

National Cancer Institute

\section{Source}

National Cancer Institute. PTPRT wt Allele. NCI Thesaurus. Code C49540.

Human PTPRT wild-type allele is located within 20q12-q13 and is approximately $1117 \mathrm{~kb}$

in length. This allele, which encodes receptor-type tyrosine-protein phosphatase $T$

protein, is involved in the dephosphorylation of protein-tyrosine phosphates. 